\title{
ANALISIS VALUE ENGINEERING PADA PROYEK PERUMAHAN DJAJAKUSUMAH RESIDENCE
}

\author{
Hanifah Amelia', Hendrik Sulistio ${ }^{2}$ \\ ${ }^{1}$ Program Studi Sarjana Teknik Sipil, Universitas Tarumanagara, Jl. Letjen S. Parman No.1 Jakarta \\ Email: hanifah.ameliaa@gmail.com \\ ${ }^{2}$ Program Studi Doktor Teknik Sipil, Universitas Tarumanagara, Jl. Letjen S. Parman No.1 Jakarta \\ Email: hendriks@ft.untar.ac.id
}

\begin{abstract}
ABSTRAK
Pemilihan material pada konstruksi sebuah bangunan merupakan suatu hal yang sangat penting untuk mencapai perencanaan proyek yang efisien. Terdapat berbagai macam pilihan material mulai dari material komposit sampai dengan material non komposit. Dengan menggunakan value engineering dapat memungkinkan tercapainya perencanaan proyek yang efisien. Pada proyek perumahan djajakusumah residence terdapat beberapa pekerjaan konstruksi. Pekerjaan dinding merupakan salah satu pekerjaan yang memiliki biaya tertinggi sehingga memiliki kemungkinan untuk dilakukan value engineering. Penelitian ini bertujuan untuk memndapatkan pilihan material terbaik untuk pekerjaan dinding menggunakan value engineering. Alternatif yang terdapat untuk pilihan material dinding dalam penelitian ini adalah bata merah, batako dan m-panel. Material dinding pada desain awal proyek djajakusumah residence adalah bata ringan. Metode yang digunakan untuk pengambilan keputusan dalam penelitian ini dengan membandingkan antara net present value (NPV) dengan value masing-masing alternatif. Didapatkan hasil perbandingan antara NPV dengan value untuk desain awal bata ringan sebesar 5.34, bata merah sebesar 5.46, batako sebesar 4.87, dan m-panel sesbesar 5.05. Berdasarkan perbandingan tersebut didapatkan bahwa yang tertinggi adalah bata merah dengan hasil perbandingan 5.46 dan biaya konstruksi yang dimiliki bata merah adalah Rp52,942,866,059.83, sehingga menghemat biaya desain awal sebesar Rp 258,762,864.47. Dapat dinyatakan bahwa bata merah merupakan alternatif yang terbaik pada proyek perumahan djajakusumah residence.
\end{abstract}

Kata kunci: Value engineering, Net Present Value, Material

\section{PENDAHULUAN}

\section{Latar belakang}

Dalam satu pekerjaan konstruksi dapat memiliki beberapa metode pekerjaan dan pilihan material. Mulai dari yang menggunakan bahan konvesional hingga menggunakan bahan alternatif yang sekarang sudah banyak dikembangkan. Bahan material konvensional merupakan sebutan dari bahan material yang umumnya dipakai untuk membangun sebuah konstruksi yang berasal dari alam. Bahan material alternatif tumbuh dan berkembang seiring perkembangan zaman.

Bahan material merupakan komponen utama pada setiap kegiatan konstruksi. Bila ada kesalahan dalam penggunaan atau pemilihan material dapat berimplikasi kepada biaya dan waktu pada sebuah konstruksi. Jika volume material rencana melebihi material yang sebenarnya akan timbul waste material. Oleh karena itu, perencanaan material harus dilakukan dengan baik agar waste material yang dihasilkan tidak banyak, begitu pula dengan waktu dan biaya tidak mengalami pembengkakan.

Untuk mendapatkan biaya dan waktu yang efisien dapat dilakukan dengan metode rekayasa nilai yang dapat membantu menentukan material yang baik dan sesuai untuk suatu proyek. Rekayasa nilai merupakan suatu pendekatan untuk mentukan alternatif-alternatif untuk dapat mengurangi biaya yang tidak dibutuhkan tanpa harus mengurangi mutu dan fungsinya. Seperti yang dikatakan dalam jurnal yang berjudul Value Engineering and Its Applications in Civil Engineering "VE describes the process of defining alternative solutions that can provide the same functions at an equal or better level as the originally presented idea while simultaneously reducing costs and adding benefits." (Sanchez, Grecia dan Linda Navarro, 2018) 


\section{Rumusan masalah}

Rumusan masalah yang terdapat pada penelitian ini adalah sebagai berikut :

1. Apakah alternatif yang terpilih setelah dilakukan value engineering pada proyek perumahan djajakusumah residence?

2. Berapa besar saving cost yang terjadi setelah dilakukan metode value engineering?

\section{Tujuan penelitian}

Tujuan dari penelitian ini adalah sebagai berikut:

1. Dapat mengetahui alternatif yang terpilih setelah dilakukan value engineering pada proyek perumahan djajakusumah residence.

2. Dapat mengetahui hasil saving cost yang terjadi setelah dilakukan value engineering.

\section{Batasan penelitian}

Batasan dari penelitian ini adalah sebagai berikut:

1. Penelitian ini akan membahas tentang kemungkinan alternatif value engineering yang bisa dilakukan pada pekerjaan dinding.

2. Penelitian dilakukan pada proyek perumahan sebanyak 118 unit.

3. Perhitungan menggunakan AHSP Dirjen PU 2016.

\section{TINJAUAN PUSTAKA}

\section{Proyek konstruksi}

Proyek konstruksi merupakan kumpulan beberapa kegiatan dalam membangun suatu bangunan dengan waktu dan biaya yang terbatas. Proyek pada umumnya dibagi dalam beberapa tahap, meliputi survei penyuluhan, studi kelayakan, perencanaan teknis (awal), perencanaan detail (detail desain) dan pelaksanaan konstruksi

\section{Manajemen Proyek}

Manajemen konstruksi adalah suatu proses manajemen untuk pelaksanaan konstruksi dalam rangka untuk mencapai sasaran, dalamabentuk produk konstruksi secara rasional, efisien, dan efektif. Manajemen konstruksi adalah suatu cara untuk mengelola pelaksanaanaproyek dimana tahapan pelaksanaan diperlukan sebagai satu kesatuan sistem membangun (Lantang, 2014). Manajamen konstruksi digunakanakarena memiliki banyak keuntungan dari berbagai aspek. Keuntungan tersebut dapat ditinjau dari aspek biaya, aspek mutu, aspek waktu dan aspekalainnya.

\section{Perencanaan Biaya}

Yang dimaksud dengan perencanaan dan biaya ini adalah merencanakan sesuatu dalam bentuk faedah dalam penggunaannya, beserta besar biaya yang diperlukan dan susunan-susunan pelaksanaan dalam bidang administrasi maupun pelaksanaan kerja dalam bentuk teknik. Perencanaan biaya suatu bangunan atau proyek ialah perhitungan biaya yang diperlukan untuk bahan dan upah, serta biaya-biaya yang berhubungan dengan pelaksanaanabangunan dan proyek tersebut. Perencanaan biaya nyata/aktual adalah proses perhitungan volume pekerjaan, harga dari berbagai macamabahan dan pekerjaan pada suatu bangunan atau proyek bedasarkan data-data yang sebenarnya. Kegiatan perencanaan merupakan dasar untuk membuat sistem pembiayaan dari jadwal pelaksanaan konstruksi, untuk meramalkan kejadian pada suatu bangunan atau proyek, berdasarkan data-data yang sebenarnya (Lantang, 2014).

Rencana anggaran Biaya (RAB) proyek adalah perhitungan banyaknya biaya yang diperlukan untuk bahan dan upah, serta biaya-biaya lain yang berhubungan dengan pelaksanaan bangunan atau proyek tersebut (Ibrahim, 2001). Harga satuan pekerjaan (HSP) adalahabiaya yang dihitung dalam suatu analisis harga satuan suatu pekerjaan, yang terdiri atas biaya langsung (tenaga kerja, bahan, dan alat), dan biaya tidak langsung (biaya umum atau overhead, dan keuntungan) sebagai mata pembayaran suatu jenis pekerjaan tertentu, termasuk pajak-pajak. Analisis Harga Satuan Pekerjaan (AHSP) merupakanaperhitungan kebutuhan biaya tenaga kerja, bahan dan peralatan untuk mendapatkan harga satuan atau satu jenis pekerjaan tertentu. 


\section{Value engineering}

Value engineering atau rekayasa nilai merupakan pendekatan yang dapat membandingkan beberapa alternatif sehingga dapat membuat biaya yang dibutuhkan menjadialebih efisien. Value engineering adalah suatu sistem pemecahan masalah yang dilaksanakan dengan menggunakan kumpulan teknik tertentu, ilmu pengetahuan, tim ahli - pendekatan kreatifateroganisasi yang memiliki tujuan untuk mengidentifikasi secara efisien biayaa yang tak diperlukan seperti biaya yang tidak menghasilkan kualitas, kegunaan, umur, dan penampilan produk serta daya tarik terhadap konsumen menurut Lawrence D. Miles.

Penerapan value engineering dilakukan secara sistematis dan kreatif guna mendapatkan penghematan biaya namun tetap dalam batasan fungsinya. Menurut Irsan Ilyas, tidak ada pihak manapun yang dirugikan oleh VE baik owner, konsultan, kontraktor, maupun pengguna jasa sebab dengan teknik VE memungkinkan pengguna jasa, perencana dan kontraktor untuk bersama-sama mempelajari kriteria dari suatu kegiatan guna menghasilkan penghematan biaya dari pelaksanaan suatu produk atau sistem tertentu.

(Kurniawan, 2009) dalam tesisnya menyebutkan sebelum menerapkan suatu program value engineering dalam suatu proyek khususnya proyek konstruksi fisik, perlu terlebih dulu diperjelas mengenai pengertian dari value engineering itu sendiri untuk menghindari kesan terutama dari perancang bahwa kegiatan value engineering adalah kritikan untuk rancangan/desain suatu proyek tanpa melibatkan aspek-aspek teknis.

\section{Material Konstruksi}

Besarnya jumlah material yang dibutuhkan harus sesuai dengan kebutuhan proyek. Jika jumlah material mengalami kekurangan maka kegiatan proyek akan terhambat, dan harus menunggu sampai kedatangan material yang mencukupi. Hal ini dapat dihindari dengan cara membeli material sebanyak mungkin sebelum permintaan akan material ini datang. Namun penyelesaian dengan cara ini memiliki kerugian karena semakin banyak material yang dibeli sebelum waktunya digunakan berarti semakin banyak pula modal yang tertanam dalam bentuk jumlah persediaan sehingga tidak dapat digunakan untuk keperluan yang lebih menguntungkan.

\section{METODOLOGI PENELITIAN}

Data yang digunakan pada penelitian ini adalah data pada proyek perumahan djajakusumah residence yang memiliki 118 unit rumah, setiap rumahnya memiliki 2 lantai. Proyek perumahan djajakusumah residence berada di daerah Tangerang Selatan.

Pengumpulan data dalam penilitian ini dilakukan dengan beberapa cara yaitu, untuk data primer dilakukan dengan wawancara dan observasi lapangan. Data sekunder yang dibutuh kan adalah gambar kerja, rencana anggaran biaya, daftar harga satuan pekerjaan dan rencana kerja.

Data yang sudah ada akan dilakukan breakdown cost dan pembuatan diagram pareto untuk mengetahui pekerjaan yang termasuk biaya tertinggi dan dapat dilakukan value engineering. Tahap value engineering yang dilakukan setelah mengetahui pekerjan yang akan ditinjau yaitu, tahap analisis fungsi dengan membuat FAST diagram, tahap kreatif dengan menginformasikan alternatif yang dapat dilakukan pada pekerjaan yang ditinjau, tahap evaluasi dan pengembangan dengan memaparkan kelebihan dan kekurangan dari masing-masing alternatif, tahap evaluasi kriteria dengan menyebutkan kriteria yang akan ditinjau dan mencari bobot masing-masing kriteria, tahap selanjutnya adalah menghitung net present value dan value index.

Value Index = NPV / material value

dengan, NPV = Net Present Value (Selisih cash out dan cash in) 


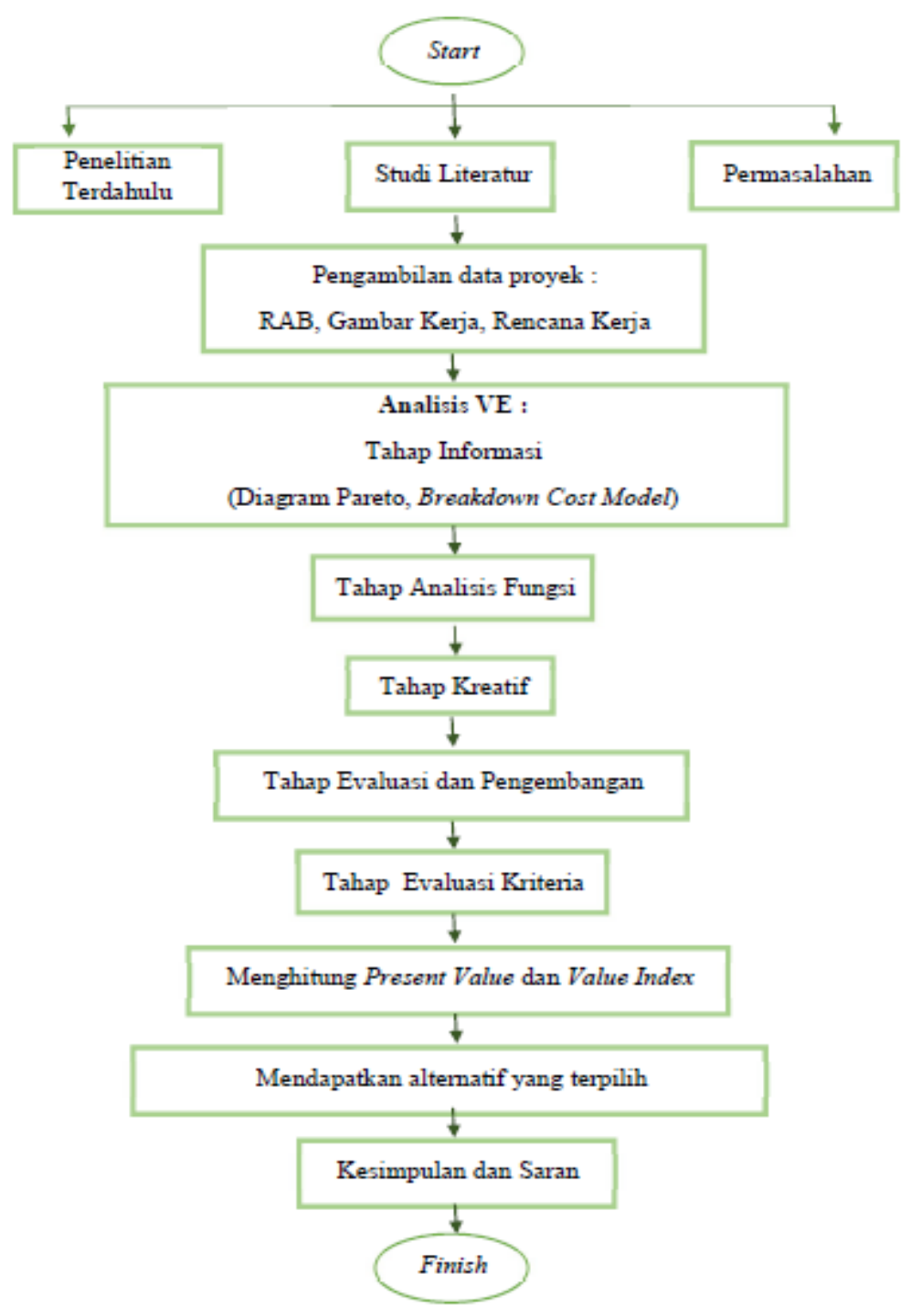

Gambar 1. Diagram alir

\section{PEMBAHASAN DAN HASIL}

\section{Tahap informasi}

Tahap ini merupakan pemaparan rancangan anggaran biaya (RAB) dimiliki proyek sebagai dasar pemilihan pekerjaan yang akan dilakukan value engineering. Berdasarkan tabel 1. dan gambar 2. diagram pareto pekerjaan dinding/beton menunjukkan bahwa pekerjaan yang termasuk pada pekerjaan yang memiliki biaya tertinggi pada sub pekerjaan tersebut adalah plesteran \& acian, dinding hebel, pelat beton dan balok beton. Pekerjaan pelat beton dan balok memiliki kemungkinan kecil untuk dilakukannya value engineering karena 2 pekerjaan tersebut sudah memakai persyaratan minimum yang diperbolehkan oleh peraturan seperti, tebal pelat beton $12 \mathrm{~cm}$. Kemungkinan pekerjaan yang dapat dilakukan value engineering adalah pekerjaan dinding yang dapat mempengaruhi juga pekerjaan plesteran dan acian tergantung pada jenis bahan apa yang digunakan pada pekerjaan dinding. 
Tabel 1. RAB pekerjaan beton dan dinding

\begin{tabular}{lcccr}
\hline NO. NAMA PEKERJAAN & BOBOT & $\begin{array}{c}\text { BOBOT } \\
\text { KUMULATIF }\end{array}$ & \multicolumn{2}{c}{ BLAYA } \\
\hline 1 Plesteran \& Acian & $26.78 \%$ & $26.78 \%$ & $\mathrm{Rp}$ & $6,361,786,990.00$ \\
\hline 2 Dinding Hebel & $19.13 \%$ & $45.91 \%$ & $\mathrm{Rp}$ & 4.544 .113 .220 .00 \\
\hline 3 Plat Beton & $16.92 \%$ & $62.83 \%$ & $\mathrm{Rp}$ & 4.019 .617 .190 .00 \\
\hline 4 Balok Beton & $13.64 \%$ & $76.47 \%$ & $\mathrm{Rp}$ & $3,240,966,780.00$ \\
\hline 5 Kolom Beton & $10.80 \%$ & $87.27 \%$ & $\mathrm{Rp}$ & $2,566,845,310.00$ \\
\hline 6 Sloof & $5.75 \%$ & $93.03 \%$ & $\mathrm{Rp}$ & $1,366,044,190.00$ \\
\hline 7 Ring Balok & $2.46 \%$ & $95.49 \%$ & $\mathrm{Rp}$ & $584,925,340.00$ \\
\hline 8 Dinding Keramik & $1.89 \%$ & $97.38 \%$ & $\mathrm{Rp}$ & $448,781,380.00$ \\
\hline 9 Meja Dapur & $1.32 \%$ & $98.70 \%$ & $\mathrm{Rp}$ & $314,346,340.00$ \\
\hline 10 Topi Beton + Expose & $0.92 \%$ & $99.62 \%$ & $\mathrm{Rp}$ & $218,884,170.00$ \\
\hline 11 Dinding KM Pembantu & $0.38 \%$ & $100.00 \%$ & $\mathrm{Rp}$ & $90,050,590.00$ \\
\hline & & TOTAL BLAYA & $\mathrm{Rp}$ & $23,756,361,500.00$ \\
\cline { 3 - 5 }
\end{tabular}

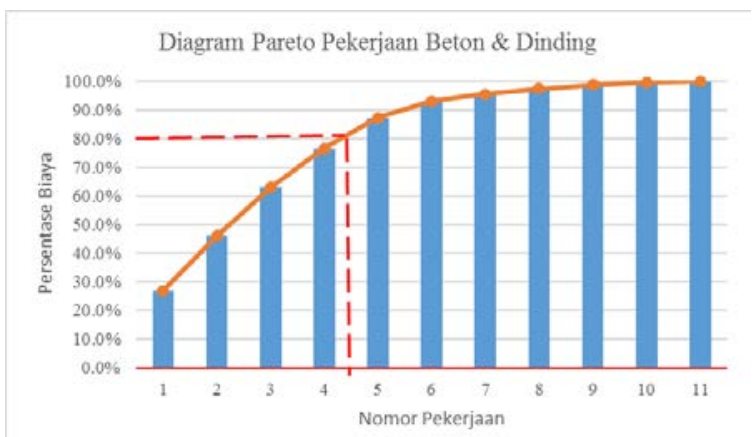

Gambar 2. Diagram pareto pekerjaan beton dan dinding

\section{Tahap evaluasi kriteria}

Tahap evaluasi kriteria dilakukan setelah melalui tahap analisis fungsi dengan membuat diagram fast, tahap kreatif dan tahap evaluasi dan pengembangan, sehingga sudah diketahui fungsi dan alternatif yang digunakan serta kelebihan dan kekurangan pada masing-masing alternatif. Akternatif yang digunakan adalah bata ringan (desain awal), bata merah, batako dan m-panel. Tahap evaluasi kriteria melakukan pencarian bobot setiap kriteria dengan matriks yang diisikan oleh beberapa responden yang bekerja dibidang konstruksi. Pada matriks diisikan nilai 0 sampai 5, 0 jika kedua kriteria sama penting, 5 jika hanya satu kriteria yang sangat penting dan 1-4 diantarnya. Dapat dilihat pada gambar 3.

\begin{tabular}{|c|c|c|c|c|c|c|c|c|c|}
\hline & & A & B & C & D & $E$ & $\mathrm{~F}$ & & \\
\hline & & Biaya & $\begin{array}{c}\text { Berat } \\
\text { material }\end{array}$ & Kekuatan & $\begin{array}{c}\text { Fire } \\
\text { resistance }\end{array}$ & $\begin{array}{l}\text { Kemudahan } \\
\text { pelaksanaan }\end{array}$ & $\begin{array}{c}\text { material } \\
\text { pendukung }\end{array}$ & Total & Bobot \\
\hline A & Biaya & & A-1 & $\mathrm{A}-2$ & $A-2$ & $\mathrm{E}-2$ & A-3 & 8 & 0.3076923 \\
\hline B & Berat material & & & C-3 & D-2 & E-2 & B-1 & 1 & 0.0384615 \\
\hline C & Kekuatan & & & & C-1 & C-1 & C-1 & 6 & 0.2307692 \\
\hline D & Fire resistance & & & & & E-1 & $\mathrm{F}-2$ & 2 & 0.0769231 \\
\hline E & $\begin{array}{l}\text { Kemudahan } \\
\text { pelaksanaan }\end{array}$ & & & & & & $\mathrm{E}-2$ & 7 & 0.2692308 \\
\hline F & $\begin{array}{c}\text { Material } \\
\text { pendukung }\end{array}$ & & & & & & & 2 & 0.0769231 \\
\hline
\end{tabular}

Gambar 3. Contoh pemberian nilai

Dilanjutkan dengan pemberian peringkat pada masing-masing alternatif berdasarkan kriteria dengan angka 0-10 semakin besar angka yang diberikan maka material semakin menguntungkan. Pemberian peringkat seperti tabel 2. Setelah pemberian peringkat dilanjutkan dengn menghitung material value dengan cara mengkalikan peringkat dengan bobot kriteria dapat dilihat pada tabel 3. 
Tabel 2. Contoh pemberian peringkat

\begin{tabular}{lccccc}
\hline \multicolumn{1}{c}{ Kriteria } & Bobot & $\begin{array}{c}\text { Bata } \\
\text { Ringan }\end{array}$ & Bata Merah & Batako & Panel \\
\hline Biaya & 0.307692 & 2 & 4 & 6 & 1 \\
\hline Berat Material & 0.038462 & 7 & 5 & 7 & 1 \\
\hline Kekuatan & 0.230769 & 6 & 6 & 2 & 8 \\
\hline Fire Resi stance & 0.076923 & 4 & 5 & 2 & 8 \\
\hline Kemudahan Pelaksanaan & 0.269231 & 8 & 7 & 7 & 9 \\
\hline Material Pendukung & 0.076923 & 8 & 6 & 7 & 9 \\
\hline
\end{tabular}

Tabel 3. Contoh penghitungan material value

\begin{tabular}{lccccc}
\hline \multicolumn{1}{c}{ Kriteria } & Bobot & Bata Ringan & Bata Merah & Batako & Panel \\
\hline Biaya & 0.28571 & 0.61538 & 1.23077 & 1.84615 & 0.30769 \\
\hline Berat Material & 0.03571 & 0.26923 & 0.19231 & 0.26923 & 0.03846 \\
\hline Kekuatan & 0.21429 & 1.38462 & 1.38462 & 0.46154 & 1.84615 \\
\hline Fire Resistance & 0.07143 & 0.30769 & 0.38462 & 0.15385 & 0.61538 \\
\hline Kemudahan Pelaksanaan & 0.25000 & 2.15385 & 1.88462 & 1.88462 & 2.42308 \\
\hline Material Pendukung & 0.14286 & 0.61538 & 0.46154 & 0.53846 & 0.69231 \\
\hline \multicolumn{1}{c}{ Total } & & 5.34615 & 5.53846 & 5.15385 & 5.92308 \\
\hline
\end{tabular}

\section{Perhitungan Net Present Value (NPV)}

Perhitungan NPV pada masing-masing alternatif berasal dari selisih pemasukkan dan pengeluaran proyek seperti pada tabel 4. dan tabel 5 .

Tabel 4. Pemaparan pemasukkan dan pengeluaran proyek

\begin{tabular}{|c|c|c|c|c|c|c|}
\hline & & Bata Ringan & & Bata Merah & Batako & M-Panel \\
\hline Luas lahan kotor (m2) & & 25782 & & 25782 & 25782 & 25782 \\
\hline Luas lahan bersih (m2) & & 14180 & & 14180 & 14180 & 14180 \\
\hline Biaya pemb elian tanah (Rp) & $R_{p}$ & $53,277,964,380.00$ & $R p$ & $53,277,964,380.00$ & $53,277,964,380.00$ & $53,277,964,380.00$ \\
\hline Total bangunan (unit) & & 118 & & 118 & 118 & 118 \\
\hline Biaya Konstrulsi (Rp) & $R_{p}$ & $53,201,743,967.09$ & $R_{p}$ & $52,942,866,059.83$ & $52,024,358,891.93$ & $53,203,850,282.43$ \\
\hline Maintenance ( $R p)$ & $R p$ & $106,403,487.93$ & $R_{p}$ & $106,518,530.72$ & $130,060,897.23$ & $106,407,700.56$ \\
\hline Biaya lain-lain (Rp) & $\mathrm{Rp}_{\mathrm{p}}$ & $38,697,324,000.00$ & $\mathrm{Rp}$ & $38,697,324,000.00$ & $38,697,324,000.00$ & $38,697,324,000.00$ \\
\hline Harga pembelian tumah & $R_{p}$ & $174,340,123,002.03$ & $R p$ & $174,409,286,724.66$ & $165,749,164,394.53$ & $174,342,655,635.59$ \\
\hline
\end{tabular}

Tabel 5. Perhitungan NPV

\begin{tabular}{|c|c|c|c|c|c|c|c|c|}
\hline & \multicolumn{2}{|r|}{ Bata Ringan } & & Bata Merah & \multicolumn{2}{|r|}{ Batako } & \multicolumn{2}{|r|}{ M-Pane1 } \\
\hline Total Pengehv aran & $R_{p}$ & $145,283,435,835.02$ & $R_{p}$ & $145,024,672,970.55$ & $R p$ & $144,129,708,169.16$ & $R p$ & $145,285,546,363.00$ \\
\hline Total pemasulkan & $R p$ & $174,340,123,002.03$ & $R_{p}$ & $174,029,607,564,66$ & $R p$ & $165,749,164,394.53$ & $\mathrm{Rp}$ & $174,342,655,635.59$ \\
\hline NPV & $R_{p}$ & $29,056,687,167.00$ & $\mathrm{Rp}_{\mathrm{p}}$ & $29,004,934,594.11$ & $R_{p}$ & $21,619,456,225,37$ & $\mathrm{Rp}$ & $29,057,109,272.60$ \\
\hline
\end{tabular}

Didapatkan NPV masing-masing alternatif yang tertinggi adalah M-Panel sebesar Rp 29,057,109,272.60 dan yang terendah adalah batako sebesar Rp29,004,934,594.11

\section{Perhitungan value index}

Perhitungan value index merupakan pembagian antara NPV dan material value setiap alternatif seperti pada tabel 6. Value index tertinggi merupakan alternatif yang terpilih. 
Tabel 6. Value index

\begin{tabular}{lcccc}
\hline & Bata Ringan & Bata Merah & Batako & M-Panel \\
\hline NPV (miliyar rupiah) & 29.05668717 & 29.00493459 & 21.61945623 & 29.05710927 \\
\hline Material Vadue & 5.442729734 & 5.306443393 & 4.437047198 & 5.758127707 \\
\hline NPV/VE & 5.338623923 & 5.465983983 & 4.872487324 & 5.046277323 \\
\hline
\end{tabular}

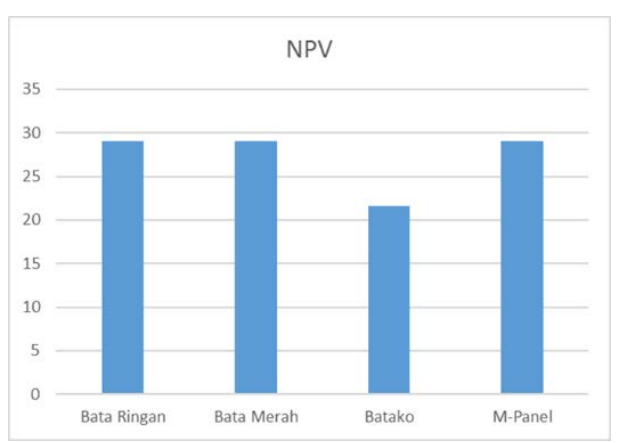

Gambar 4. Diagram NPV

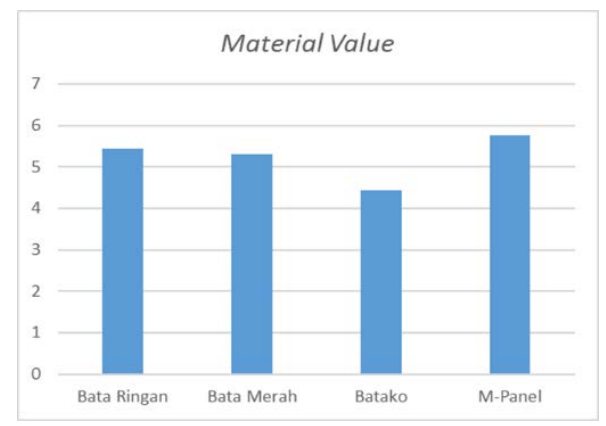

Gambar 5. Diagram NPV

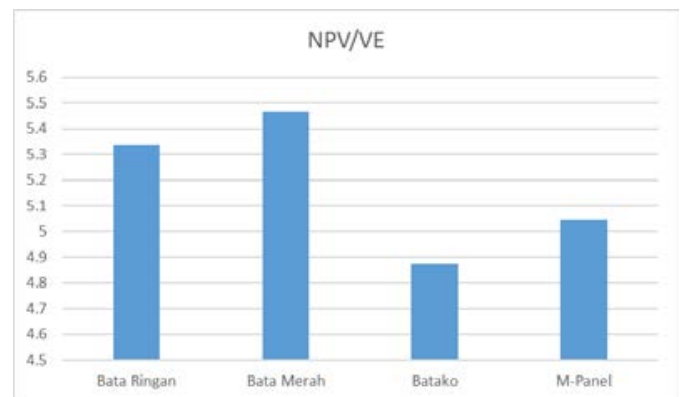

Gambar 6. Diagram value index

\section{KESIMPULAN}

1. Dari alternatif-alternatif yang ada pada pekerjaan dinding yang terpilih sebagai pengganti material bata ringan adalah bata merah berdasarkan penilaian pada material value dan juga net present value material 
tersebut. Dengan penilaian untuk material value tersebut adalah 5.31 dan net present value yang dimiliki adalah Rp 29,004,934,594.11

2. Berdasarkan perbandingan antara material value dan net present value masing-masing alternatif didapatkan bahwa bata merah merupakan yang tertinggi sebesar 5.46 dan batako merupakan yang terendah sebesar 5.05 .

3. Berdasarkan alternatif yang terpilih saving cost yang terjadi sebesar Rp 258,762,864.47.

\section{SARAN}

1. Penggunaan material dinding bata merah disarankan pada perumahan djajakusumah residence berdasarkan perbandingan NPV dengan material value.

2. Pemberian bobot kriteria lebih baik diisikan dari berbagai divisi pada bidang konstruksi untuk mendapat value yang tepat.

3. Pada penelitian selanjutnya untuk mendapatkan hasil yang lebih akurat, perlu ditambah kriteria dan juga alternatif yang ditinjau.

\section{DAFTAR PUSTAKA}

Borza, John. (2011). FAST Diagram:The Foundation. for Creating Effective Function Models. Trizcon Detroit.

El-Nashar, Walaa Younes dan Ahmed Hussien E. (2017). Value Engineering For Canal Tail Irrigation Water Problem. Ain Shams Engineering Journal.

El-Nashar, Walaa Younes. (2017). Effect of drains coverings on environment by using value engineering. Alexandria Engineering Journal.

Hansen, Seng. (2017). Quantity Surveying. Jakarta: PT. Gramedia Pustaka Utama

Ibrahim, Bachtiar. (2001). Rencanaadan Estimate Real of Cost. Jakarta: PT. Bumi Aksara.

Khamelda, Lila, Benedictus Sonny Yoedono dan Anna Chatarina S.P.S. (2018). Perbandingan Karakteristik, Biaya dan Waktu Material Dinding Komposit dan Non Komposit. Jurnal Ilmiah Teknik Sipil dan Teknik Kimia. Vol. 3: 108-121.

Kurniawan, Vincentius Utoro. (2009). Penerapan Value Engineering dalam Penyelenggaraan Infrastruktur Bidang Ke-PU-an di Lingkungan Departemen Pekerjaan Umum dalam Usaha Meningkatkan Efektivitas Penggunaan Anggaran. Tesis . Depok: Universitas Indonesia.

Lantang, Fharel Novel. (2014). Perencanaan Biaya Dengan Menggunakan Perhitungan Biaya Nyata pada Proyek Perumahan (Studi Kasus Perumahan Green Hill Residence). Jurnal Sipil Statik. Vol.2: 73-80.

M, Diolana Prian dan Ferry Kurniawan A. (2017). Analisis Perbandingan Waktu, Biaya dan Direct Waste Pengguna Tulangan Konvensional, Wire Mesh dan Floordeck Pada Pekerjaan Plat Lantai. Jurnal Karya Teknik Sipil. Vol.6: 69-80.

Onibala, Etika Christin, Revo L. Inkiriwang dan Mochtar Sibi. (2018). Metode Pelaksanaan Pekerjaan Konstruksi Dalam Proyek Pembangunan Sekolah SMK Santa Familia Kota Tomohon. Jurnal Sipil Statistik. Vol.6: 927-940.

Putra, Nyoman Dita Pahang dan Mudjahidin. (2009). Value Engineering Pembangunan Rusunawa. Jurnal Teknik Industri. Vol. 10, 173-179.

Pratiwi, Rahmawati Eka. (2012). Analisis Pengaruh Cost Management Terhadap Efisiensi pada Proyek Konstruksi Studi pada Perusahaan PT. Adhi Karya (Persero) Tbk. Jurnal Bisnis Strategi. Vol. 21: 62-71

Sanchez, Grecia dan Linda Navarro. (2018). Value Engineering and Its Applications in Civil Engineering. Construction Research Congress.

Sasongko, Rinto. (2018). Survey Rekayasa Konstruksi. Malang: Polinema Press.

Simatupang, Juan Sebastian. (2015). Pengaruh Percepatan Durasi Terhadap Waktu pada Proyek Konstruksi (Studi Kasus : Pembangunan Persekolahan Eben Haezar Manado). Jurnal Sipil Statik. Vol. 3: 281-291.

Sugiarto, Teguh. Pengertian proyek konstruksi. Tersedia di www: https://docplayer.info/29762607-A-pengertianproyek-konstruksi.html (10 Juni 2019). 